\title{
Effect of curcumin, anise seed ground and their interaction on the immunological parameters of broiler chickens and the efficiency of nitrogen, calcium and phosphorus retention percentage
}

\author{
El-hadi A. M. ${ }^{*}$, Metwally M. A. ${ }^{2}$, Issa N. M. ${ }^{1}$ \\ ${ }^{1}$ Department of Animal Production (Poultry Division), Faculty of Agriculture, Al-Azhar University, Assiut, Egypt \\ ${ }^{2}$ Department of Poultry Production, Faculty of Agriculture, Assiut University, Assiut, Egypt
}

\begin{abstract}
The present work aimed to study the effect of feeding broiler chicks on diets containing different levels of curcumin, anise ground seeds and their interactions as natural feed additive on immune response and nitrogen, calcium and phosphorus retention efficiency percentage and economical evaluation. A total of 297, one-day-old Ross308 broiler chickens were randomly allocated to nine experimental treatments with three replications of eleven birds each $(3 \times 3)$. Three curcumin levels $(0,50$ and $100 \mathrm{mg} / \mathrm{kg})$ and 3 anise ground seeds levels $(0,0.50$ and $1 \%)$ added to basal diet. The results showed that there was a significant $(P<0.05)$ improvement in IgM for birds fed on diets containing anise seeds $(0.5$ or $1 \%$ in diet). There was significant $(P<0.05)$ effect due to interactions of curcumin and anise levels on $\operatorname{IgG}$ at age 21 day and $\operatorname{IgA}$ at age 42 day. There was no significant effect of curcumin, anise seed alone and interactions on the bursa percentage and spleen percentage at the age of 42 days. The results also showed a decrease in nitrogen retention efficiency percentage in birds fed diets containing curcumin at age 43-45 day. The rate of calcium retention efficiency percentage decreased in birds fed diets containing anise seeds at age of 43-45 days. It was recommended that curcumin as medical herbs should be add at level of $50 \mathrm{mg} / \mathrm{kg}$ diet or $100 \mathrm{mg} / \mathrm{kg}$ curcumin plus $0.5 \%$ anise ground seeds to achieve higher immunity of broiler chicken (Ross 308).
\end{abstract}

Keywords: broilers, curcumin, anise seeds, performance, immunity. 


\section{Introduction}

There are many feed additives used in broiler diets. The most common spice that can be used as feed additive for fattening diets (Zhang et al., 2009) including ginger, black cumin, thyme, garlic, coriander, and turmeric (Murugesan et al., 2015). As medicinal herbs contain compounds of great benefits and importance due to their physiological effect and therapeutic activity on humans and animals (Mutlaq and Sadik, 2012). Among these medicinal plants are turmeric (Curcuma longa) and anise seed (Pimpinella anisum L.). Turmeric is a member of Zingiberacae family and contains curcumin, demethoxycurcumin, bisdemethoxycurcumin and tetrahydrocurcuminoids as active constituents (Kiuchi et al., 1993). One of the natural compounds is curcumin, the extract from herbal plant Curcuma longa, known for its antioxidant and antimicrobial properties which may be effective in reducing coccidian infection in poultry. The main Igs in poultry are IgA, $\mathrm{IgG}$, and $\mathrm{IgM}$, and the contents of these 3 Ig in serum can represent the overall level of serum Ig in laying hens. Previous studies have shown that heat stress reduces the level of Ig in the blood of animals (Abe et al., 1999), whereas curcumin has the effect of improving immunity. Furthermore, curcumin supplementation in a diet for rabbits at levels $(2,4$ and $6 \mathrm{~g} / \mathrm{kg})$ significantly increased serum levels of $\operatorname{IgG}$ and $\operatorname{IgM}$, suggesting that curcumin can also improve immune function (Alagawany et al., 2016). The results of that study showed that different levels of curcumin in the diet could increase the level of Ig in the serum of laying hens to different degrees in summer. Badran et al. (2020) found that immunoglobulin $\mathrm{M}$ (IgM) improved in broiler chicks at 3 and 5 weeks of age when fed diets containing curcumin at levels of (50 or $100 \mathrm{mg} / \mathrm{kg}$ ) compared to the control. While immunoglobulin $\mathrm{G}$ ( $\mathrm{IgG}$ ) in broiler chickens that fed diets containing curcumin at levels $(50 \mathrm{mg} / \mathrm{kg}$ diet $)$ compared to the control at 3 and 5 weeks old. In this context, there was no significant effect on spleen percentage, bursa of fabricius percentage when feeding chicks with diets fed diets containing turmeric at levels of $(0.5 \%$ or $1 \%)$ compared to the control at age35 day (Sahoo et al., 2019). On the other hand, Amein et al. (2019) found that feeding broiler chicks diets containing $0.3 \%$ or $0.5 \%$ turmeric enhanced total feed cost, total production cost, economic feed efficiency percentage and relative economic feed efficiency compared to control group. Anise (Pimpinella anisum L.) is a yearly aromatic plant found in Iran, India, Turkey and Egypt and several other warm areas in the world (Ramadan, 2017). They contain 2-6\% of essential oils, phenolic acids, eugenol, estragole, and trans-anethole, which is a powerful phytoestrogen and the main component of the oil (80-95\%) (Christaki et al., 2012). Yazdi et al. (2014) found that there was no significant effect on spleen percentage when feeding chicks with diets containing anise seeds $(1,5$ and $10 \mathrm{gm} / \mathrm{kg}$ ) compared to control. Amein et al. (2019) found that enhanced total feed cost, total production cost, economic feed efficiency $\%$ and relative economic feed efficiency high in anise seeds containing feeds $(0.3$ and $0.6 \%$ ) compared to control. The present 
study was designed to study the effect of graded levels of curcumin or anise seeds and their interactions on immunity status, economical evaluation and nitrogen, calcium and phosphorus retention efficiency percentage of broiler chicks.

\section{Materials and methods}

This study was conducted at commercial farm for broiler is located in Senbellawein city, Dakahlia governorate, Egypt in period of September 2020 and October 2020. A total number of 297 unsexed Ross 308 broiler chicks one day-old, were individually weighed. Consequently, chicks were equally distributed into 9 treatments with average body weight $(45.02 \pm 1.07 \mathrm{~g})$ and total number (of 33 chicks/treatment), each treatment further divided into 3 replicates (11 chicks each).All diets were formulated to meet or exceed (NRC, 1994) recommendations for essential amino acids in starter diet from day one to twenty-one days old of age (Table 1) and grower diet from twenty-two days to forty-two old of age (Table 2). Chicks were housed in floor pens $(1 \times 1.5 \mathrm{~m})$ and brooded throughout the experimental period on a Sawdust litter $(5-7 \mathrm{~cm})$. The chicks were reared under $32{ }^{\circ} \mathrm{C}$ temperature as standard brooding temperature and $60 \%$ relative humidity during the first week, then gradually reduced $2^{\circ} \mathrm{C}$ every three days to reach $24^{\circ} \mathrm{C}$ and $55 \%$ relative humidity. A factorial design $(3 \times 3)$ arrangement was used. Three levels of curcumin (control
(0), 50 and $100 \mathrm{mg} / \mathrm{kg}$ ) and three levels of ground anise (control, 0.5 and $1 \%$ ) were used.

\subsection{Materials purchased and preparations}

The feed ingredients were purchased from a local source and the dry matter percentage was estimated as well as crude protein, crude fiber, ash, and ether extract percentages in the fodder at Dakahlia Poultry company, Damas, Egypt using the device of NIRS ${ }^{\text {TM }}$ DS2500 Feed Analysis (Nils Foss Allé 1DK-3400 Hilleroed Denmark). Calcium and total phosphorous in the feed were chemically estimated well following the standard methods of analysis described by the Association of Official Analytical Chemists (AOAC,1990) in the Animal Production Laboratory, Faculty of Agriculture, Al-Azhar University, Assiut, Egypt.

\subsection{Criteria studied}

\subsubsection{Blood sampling}

At 21 and 42 days (end of the experiment), blood samples were randomly withdrawn and collected for 6 birds per treatments from jugular vein into heparinized tubes. Blood samples were centrifuged for 15 min at 3,000 rpm for serum separation, then serum samples were stored at $-20{ }^{\circ} \mathrm{C}$ until analysis. Serum immunoglobulins (IgG, $\operatorname{IgM}$ and $\operatorname{Ig} \mathrm{A}$ ) were determined $\mathrm{Al}$ Kawthar Laboratory, Assiut, Egypt. 
Table (1): Composition and energy value of the starter experimental diet ( $0-21$ day-old).

\begin{tabular}{|c|c|c|c|c|c|c|c|c|c|}
\hline \multirow{2}{*}{ Items } & \multicolumn{9}{|c|}{ Groups } \\
\hline & $\mathrm{T} 1$ & $\mathrm{~T} 2$ & T3 & T4 & T5 & T6 & $\mathrm{T} 7$ & T8 & T9 \\
\hline \multicolumn{10}{|c|}{ Physical composition (\%) } \\
\hline Anise seeds \% & 0 & 0.5 & 1 & 0 & 0.5 & 1 & 0 & 0.5 & 1 \\
\hline Curcumin $(\mathrm{mg} / \mathrm{Kg})$ & 0 & 0 & 0 & 50 & 50 & 50 & 100 & 100 & 100 \\
\hline Yellow corn $\%$ & 54.30 & 54.20 & 54.20 & 54.30 & 54.20 & 54.20 & 54.30 & 54.20 & 54.20 \\
\hline Soybean meal (46) \% & 36.99 & 36.79 & 36.79 & 36.99 & 36.79 & 36.79 & 36.99 & 36.79 & 36.79 \\
\hline Sunflower oil\% & 4.90 & 4.70 & 4.50 & 4.90 & 4.70 & 4.50 & 4.90 & 4.70 & 4.50 \\
\hline Di-Ca Po4\% & 1.73 & 1.73 & 1.53 & 1.73 & 1.73 & 1.53 & 1.73 & 1.73 & 1.53 \\
\hline Limestone \% & 1.33 & 1.33 & 1.23 & 1.33 & 1.33 & 1.23 & 1.33 & 1.33 & 1.23 \\
\hline DL-Methionine \% & 0.15 & 0.15 & 0.15 & 0.15 & 0.15 & 0.15 & 0.15 & 0.15 & 0.15 \\
\hline Premix \%* & 0.30 & 0.30 & 0.30 & 0.30 & 0.30 & 0.30 & 0.30 & 0.30 & 0.30 \\
\hline Common salt \% & 0.30 & 0.30 & 0.30 & 0.30 & 0.30 & 0.30 & 0.30 & 0.30 & 0.30 \\
\hline Total \% & 100.00 & 100.00 & 100.00 & 100.00 & 100.00 & 100.00 & 100.00 & 100.00 & 100.00 \\
\hline \multicolumn{10}{|c|}{ Chemical composition (\%) } \\
\hline Dry matter $\%$ & 88.84 & 88.64 & 88.40 & 88.62 & 88.50 & 88.56 & 88.37 & 88.61 & 88.64 \\
\hline Crude protein $\%$ & 22.66 & 22.72 & 22.47 & 22.18 & 22.23 & 22.40 & 22.54 & 22.43 & 22.23 \\
\hline Ether extract \% & 7.24 & 7.59 & 7.38 & 7.22 & 6.77 & 7.27 & 7.34 & 6.91 & 7.77 \\
\hline Crude fiber $\%$ & 2.61 & 2.46 & 2.25 & 3.19 & 2.44 & 2.25 & 2.57 & 3.12 & 2.42 \\
\hline NFE \% & 50.35 & 49.79 & 50.28 & 50 & 51.08 & 50.63 & 49.81 & 50.33 & 50.29 \\
\hline Ash \% & 5.98 & 6.08 & 6.02 & 6.03 & 5.98 & 6.01 & 6.11 & 5.82 & 5.93 \\
\hline Calcium \% & 1.06 & 1.22 & 1.06 & 1.30 & 1.22 & 1.30 & 0.89 & 1.14 & 1.14 \\
\hline Total phosphorus \% & 0.60 & 0.59 & 0.53 & 0.60 & 0.72 & 0.60 & 0.51 & 0.66 & 0.57 \\
\hline $\mathrm{ME}, \mathrm{Kcal} / \mathrm{kg} \mathrm{DM}$ & 3187 & 3198 & 3189 & 3155 & 3159 & 3190 & 3172 & 3151 & 3212 \\
\hline \multicolumn{10}{|c|}{ Calculated composition $(\%)$} \\
\hline Crude protein $\%$ & 21.50 & 21.40 & 21.40 & 21.50 & 21.40 & 21.40 & 21.50 & 21.40 & 21.40 \\
\hline Ether extract \% & 4.03 & 4.02 & 4.02 & 4.03 & 4.02 & 4.02 & 4.03 & 4.02 & 4.02 \\
\hline Crude fiber $\%$ & 3.84 & 3.82 & 3.82 & 3.84 & 3.82 & 3.82 & 3.84 & 3.82 & 3.82 \\
\hline Ash \% & 3.11 & 3.10 & 3.10 & 3.11 & 3.10 & 3.10 & 3.11 & 3.10 & 3.10 \\
\hline Calcium \% & 1.00 & 1.00 & 0.91 & 1.00 & 1.00 & 0.91 & 1.00 & 1.00 & 0.91 \\
\hline Total phosphorus \% & 0.72 & 0.71 & 0.68 & 0.72 & 0.71 & 0.68 & 0.72 & 0.71 & 0.68 \\
\hline Av phosphorus \% & 0.42 & 0.42 & 0.39 & 0.42 & 0.42 & 0.39 & 0.42 & 0.42 & 0.39 \\
\hline Lysine $\%$ & 1.24 & 1.23 & 1.23 & 1.24 & 1.23 & 1.23 & 1.24 & 1.23 & 1.23 \\
\hline Methionine $\%$ & 0.53 & 0.53 & 0.53 & 0.53 & 0.53 & 0.53 & 0.53 & 0.53 & 0.53 \\
\hline $\mathrm{ME}, \mathrm{Kcal} / \mathrm{kg} \mathrm{DM}$ & 3158 & 3133 & 3116 & 3158 & 3133 & 3116 & 3158 & 3133 & 3116 \\
\hline
\end{tabular}

*Each $3 \mathrm{~kg}$ of vitamin mineral premix: contains: vitamin A, 1200000IU; vitamin D3, 300000IU; vitamin E,700 $\mathrm{mg}$; vitamin K3, $500 \mathrm{mg}$; vitamin B1 $500 \mathrm{mg}$; vitamin B2 $200 \mathrm{mg}$; vitamin B6, $600 \mathrm{mg}$, vitamin B12, $3 \mathrm{mg}$; folic acid, $300 \mathrm{mg}$; choline chloride, $1000 \mathrm{mg}$; Niacin, $3000 \mathrm{mg}$; Methionine $3000 \mathrm{mg}$; Biotin $6 \mathrm{mg}$; panathonic acid $670 \mathrm{mg}$; manganese sulphat, $3000 \mathrm{mg}$; iron sulphat, $10000 \mathrm{mg}$, zinc sulphat, $1800 \mathrm{mg}$, copper sulphat 3000 $\mathrm{mg}$, iodine $1.868 \mathrm{mg}$, cobalt sulphat, $300 \mathrm{mg}$; selenium, $0.108 \mathrm{mg}$.

\subsubsection{Lymphoid organs}

At the experiment end, 27 birds were randomly taken as representative samples, three birds per treatment; one bird per replicate, the birds were individually weighed, slaughter ding. The bursa and spleen were obtained and weighed, then the percentage of each of was calculated in relation to the live body weight. 
Table (2): Chemical and calculated composition of the grower finisher diets ( $22-42$ day-old).

\begin{tabular}{|c|c|c|c|c|c|c|c|c|c|}
\hline \multirow{2}{*}{ Items } & \multicolumn{9}{|c|}{ Groups } \\
\hline & $\mathrm{T} 1$ & $\mathrm{~T} 2$ & T3 & T4 & T5 & T6 & $\mathrm{T} 7$ & $\mathrm{~T} 8$ & T9 \\
\hline \multicolumn{10}{|c|}{ Physical composition (\%) } \\
\hline Anise seeds \% & 0 & 0.5 & 1 & 0 & 0.5 & 1 & 0 & 0.5 & 1 \\
\hline Curcumin $(\mathrm{mg} / \mathrm{Kg})$ & 0 & 0 & 0 & 50 & 50 & 50 & 100 & 100 & 100 \\
\hline Yellow corn $\%$ & 61.50 & 61.40 & 61.40 & 61.50 & 61.40 & 61.40 & 61.50 & 61.40 & 61.40 \\
\hline Soybean meal (46) \% & 29.75 & 29.55 & 29.55 & 29.75 & 29.55 & 29.55 & 29.75 & 29.55 & 29.55 \\
\hline Sunflower oil\% & 4.90 & 4.70 & 4.50 & 4.9 & 4.7 & 4.5 & 4.9 & 4.7 & 4.5 \\
\hline Di-Ca Po4\% & 1.72 & 1.72 & 1.52 & 1.72 & 1.72 & 1.52 & 1.72 & 1.72 & 1.52 \\
\hline Limestone \% & 1.33 & 1.33 & 1.23 & 1.33 & 1.33 & 1.23 & 1.33 & 1.33 & 1.23 \\
\hline DL-Methionine $\%$ & 0.20 & 0.20 & 0.20 & 0.20 & 0.20 & 0.20 & 0.20 & 0.20 & 0.20 \\
\hline Premix \%* & 0.30 & 0.30 & 0.30 & 0.30 & 0.30 & 0.30 & 0.30 & 0.30 & 0.30 \\
\hline Common salt \% & 0.30 & 0.30 & 0.30 & 0.30 & 0.30 & 0.30 & 0.30 & 0.30 & 0.30 \\
\hline Total \% & 100.00 & 100.00 & 100.00 & 100.00 & 100.00 & 100.00 & 100.00 & 100.00 & 100.00 \\
\hline \multicolumn{10}{|c|}{ Chemical composition (\%) } \\
\hline Dry matter $\%$ & 88.54 & 88.44 & 88.10 & 88.41 & 88.79 & 88.84 & 88.53 & 88.33 & 88.31 \\
\hline Crude protein $\%$ & 19.61 & 19.07 & 18.89 & 19.36 & 18.74 & 18.83 & 18.47 & 18.74 & 19.20 \\
\hline Ether extract \% & 7.53 & 7.76 & 7.19 & 6.96 & 7.62 & 7.79 & 7.02 & 7.98 & 7.52 \\
\hline Crude fiber \% & 2.53 & 2.08 & 2.92 & 2.49 & 2.03 & 2.46 & 2.24 & 2.05 & 2.02 \\
\hline NFE \% & 52.76 & 53.65 & 53.01 & 53.52 & 54.6 & 54.05 & 54.86 & 53.25 & 53.5 \\
\hline Ash \% & 6.11 & 5.88 & 6.09 & 6.08 & 5.80 & 5.71 & 5.94 & 6.31 & 6.07 \\
\hline Calcium \% & 1.38 & 1.22 & 1.14 & 1.22 & 1.06 & 1.22 & 1.30 & 0.89 & 1.06 \\
\hline Total phosphorus \% & 0.60 & 0.56 & 0.55 & 0.58 & 0.54 & 0.58 & 0.66 & 0.58 & 0.62 \\
\hline $\mathrm{ME}, \mathrm{Kcal} / \mathrm{kg} \mathrm{DM}$ & 3182 & 3212 & 3137 & 3153 & 3222 & 3219 & 3172 & 3204 & 3192 \\
\hline \multicolumn{10}{|c|}{ Calculated composition (\%) } \\
\hline Crude protein $\%$ & 18.78 & 18.68 & 18.68 & 18.78 & 18.68 & 18.68 & 18.78 & 18.68 & 18.68 \\
\hline Ether extract \% & 4.38 & 4.37 & 4.37 & 4.38 & 4.37 & 4.37 & 4.38 & 4.37 & 4.37 \\
\hline Crude fiber $\%$ & 3.46 & 3.45 & 3.45 & 3.46 & 3.45 & 3.45 & 3.46 & 3.45 & 3.45 \\
\hline Ash \% & 2.73 & 2.72 & 2.72 & 2.73 & 2.72 & 2.72 & 2.73 & 2.72 & 2.72 \\
\hline Calcium \% & 0.97 & 0.97 & 0.89 & 0.97 & 0.97 & 0.89 & 0.97 & 0.97 & 0.89 \\
\hline Total phosphorus \% & 0.69 & 0.69 & 0.65 & 0.69 & 0.69 & 0.65 & 0.69 & 0.69 & 0.65 \\
\hline Av phosphorus \% & 0.40 & 0.40 & 0.36 & 0.40 & 0.40 & 0.36 & 0.40 & 0.40 & 0.36 \\
\hline Lysine \% & 1.04 & 1.04 & 1.04 & 1.04 & 1.04 & 1.04 & 1.04 & 1.04 & 1.04 \\
\hline Methionine \% & 0.55 & 0.55 & 0.55 & 0.55 & 0.55 & 0.55 & 0.55 & 0.55 & 0.55 \\
\hline $\mathrm{ME}, \mathrm{Kcal} / \mathrm{kg} \mathrm{DM}$ & 3252 & 3227 & 3211 & 3252 & 3227 & 3211 & 3252 & 3227 & 3211 \\
\hline
\end{tabular}

${ }^{*}$ Each $3 \mathrm{~kg}$ of vitamin mineral premix: contains: vitamin A, 1200000IU; vitamin D3, 300000IU; vitamin E,700 $\mathrm{mg}$; vitamin K3, $500 \mathrm{mg}$; vitamin B1 $500 \mathrm{mg}$; vitamin B2 $200 \mathrm{mg}$; vitamin B6, $600 \mathrm{mg}$, vitamin B12, $3 \mathrm{mg}$; folic acid, $300 \mathrm{mg}$; choline chloride, $1000 \mathrm{mg}$; Niacin, $3000 \mathrm{mg}$; Methionine $3000 \mathrm{mg}$; Biotin $6 \mathrm{mg}$; panathonic acid $670 \mathrm{mg}$; manganese sulphat, $3000 \mathrm{mg}$; iron sulphat, $10000 \mathrm{mg}$, zinc sulphat, $1800 \mathrm{mg}$, copper sulphat 3000 $\mathrm{mg}$, iodine $1.868 \mathrm{mg}$, cobalt sulphat, $300 \mathrm{mg}$; selenium, $0.108 \mathrm{mg}$.

\subsubsection{Economic efficiency rate (EE)}

The cost of feed consumed and selling price per bird were calculated according to the Egyptian local market prices in the year (2020). Economic feed efficiency percentage (E.E), net revenue per unit feed cost and body weight were calculated according to the following equations
(Bayoumi, 1980).Where:

$(\mathrm{A})=$ Average feed intake $(\mathrm{kg} / \mathrm{bird})$

$(B)=$ Price $/ \mathrm{kg}$ feed

$(C)=$ Total feed cost $=A$ (Average feed intake $(\mathrm{kg} / \mathrm{bird})) \times \mathrm{B}$ (Price $/ \mathrm{kg}$ feed $)$

$(D)=$ Total production cost $=\mathrm{C}($ Total feed cost $)+$ Other costs (Chicks,....etc.)

(E) = Average final body weight

$(\mathrm{F})=$ Selling price of $\mathrm{kg}$ body weight 
$(G)=$ Total revenue $=E$ (Average final body weight $) \times F$ (Selling price of kg body weight)

$(\mathrm{H})=\mathrm{Net}$ revenue $=\mathrm{G}-\mathrm{D}$ EE revenue $=\mathrm{H}(\mathrm{Net}$ revenue) / D (Total production cost)

\subsubsection{Determination of nitrogen $(N)$,} calcium $(\mathrm{Ca})$ and phosphorus $(P)$ retention efficiency

A separate experiment was carried out during the period from 43 to 45 days of age (for 3 days), the three replicate (3 birds/replicate) from each treatment were set for total collection method (Attia, 1986). Chicks were fed on their corresponding experimental diets for $72 \mathrm{~h}$, in which feed consumption and excreta voided, were accurately determined. The excreta was collected for each replicate, cleaned from feathers and feed then weighed, dried in a forced air oven at 70 ${ }^{\circ} \mathrm{C}$ for 24 hours at $105{ }^{\circ} \mathrm{C}$ for 3 hours. Samples were then finally ground and placed in screw-top glass jars until analyses. Nitrogen, calcium and phosphorus in both feed and excreta were measured by AOAC method (1990). Nutrient retention $(\mathrm{g} / \mathrm{bird})$ was calculated as nutrient intake $(\mathrm{g} / \mathrm{bird})$ minus nutrient excretion ( $\mathrm{g} / \mathrm{bird})$. Nutrient retention (\%) indicates the percentage of nutrient retained by the bird as a function of nutrient intake (Graña et al., 2013) and it was calculated as follows:

Nitrogen retention $(\%)=$ [nitrogen retained (g/bird) / nitrogen intake (g/bird) $] \times 100$

Calcium retention $(\%)=[$ calcium retained (g/bird) / calcium intake (g/bird) $] \times 100$

Phosphorus retention (\%) $=$ [phosphorus retained (g/bird) / phosphorus intake (g/bird)] $\times 100$

\subsection{Statistical analysis}

Data obtained from this study were tested for the factorial treatment design arrangement $(3 \times 3)$, three levels of curcumin and three levels of anise ground seeds by ANOVA and GLM using the SAS procedure (version 9.2, 2009). Duncan's multiple range test (1955) was also used to determine differences among means when treatment effects were significant. Significant differences were considered to exist when $(\mathrm{P}<0.05)$. The mathematical model used was:

Yijk $=\mu+$ Curi+ Anisj+ (Cur * Anis) $i j+$ eijk

Where: Yijk $=$ An observation of traits. $\mu=$ The overall mean. Curi= The fixed effect of the curcumin (where $\mathrm{i}=1,2$ and 3 ). Anisj= The fixed effect of the anised (where $\mathrm{j}=1,2$ and 3 ). (Cur *Anis) $\mathrm{ij}=$ Interaction of curcumin levels $\times$ Anis seeds percentages. eijk=The Experimental random error.

\section{Results}

3.1 Effects of curcumin, anise seeds levels and their interactions

\subsubsection{Humoral immunity}

Immunomodulatory effects of curcumin (Cur), anise ground seeds levels and their interactions are presented in Table (3) at age 21 and 42 day. The results showed 
that there were no significant $(P>0.05)$ effects of curcumin on IgG, IgM and IgA at 21 and 42 days of age. Our results are in agreement with Badran et al. (2020) who found that no significant effect immunoglobulin $\mathrm{G}(\operatorname{IgG})$ when feeding chicks with diets containing curcumin (25 or $100 \mathrm{mg} / \mathrm{kg}$ ) compared to the control at age 5 week. Also, Arshami et al. (2013) also did not observe any changes in IgG and IgM levels in laying hens supplemented with Cur powder up to $2.5 \%$ at 64 and 66 weeks of age. On the other hand, the obtained results are in disagreement with Badran et al. (2020) who reported that improved immunoglobulin $\mathrm{M}$ ( $\operatorname{IgM})$ in broiler chicks aged 3- and 5-week-old fed diets containing curcumin at levels of $(25,50$ and $100 \mathrm{mg} / \mathrm{kg}$ feed) compared to the control group. South et al. (1997) found that a significant improvement in immunoglobulin $\mathrm{G}$ ( $\mathrm{IgG}$ ) level in rats received dietary Cur at level of $40 \mathrm{mg} / \mathrm{kg}$ for 5 weeks. However, numerically improved was observed in $\operatorname{IgG}$, IgM and IgA of birds fed on diets containing curcumin at level of $50 \mathrm{mg} / \mathrm{kg}$ when compared with the control and the third level $(100 \mathrm{mg} / \mathrm{kg})$ of curcumin at 42 days of age. Regarding to the effect of ground anise seeds, there were no significant $(P>0.05)$ differences in IgG, IgM and IgA due to addition of ground anise seeds to broiler chicks at 21 and 42 days of age except IgM at age 42 day. Results showed a significantly increase in IgM at 42 days of age for the birds fed ground anise seeds at levels of $1 \%, 0.5 \%$, respectively. Our results agree with Barakat et al. (2016) who found that immunoglobulin M (IgM) was improved in broiler chickens (Cobb) fed diets containing anise seeds with levels of $(0.25,0.50$ and $0.75 \mathrm{gm} / \mathrm{kg})$ when compared to the control group at 5 weeks of age. On the other hand, the obtained results are in disagreement with Barakat et al. (2016) who reported that improved immunoglobulin A (IgA) was observed in birds (Cobb) at 3- and 5weeks old fed diets containing anise seeds at levels of $(0.25,0.50$ and $0.75 \mathrm{gm} / \mathrm{kg})$ compared to the control group. While Immunoglobulin $\mathrm{G}$ (IgG) was improved in broiler chickens (Cobb) fed diets containing anise seeds at levels of $(0.25$, 0.50 and $0.75 \mathrm{gm} / \mathrm{kg}$ ) compared to the control group at 5 weeks old. However, broiler chicks fed diets ground anise seeds with level of $(0.5 \%)$ were numerically improved in $\mathrm{IgG}$ and $\mathrm{IgA}$ when compared with the control and the group fed anise seeds at level of $(1 \%)$ at age 42 day. No significant $(P>0.05)$ effects due to the interactions between curcumin and anise ground seeds levels on IgG, IgM and IgA at 21 and 42 days of age except $\operatorname{IgG}$ at age 21 days and $\operatorname{IgA}$ at age 42 days. Decreased IgG for all interactions compared to control at 21 days of age. Group eight $(100 \mathrm{mg} / \mathrm{kg}$ curcumin and $0.5 \%$ anise seeds) was highest in IgA at 42 days old. 
Table (3): Effect of diet supplementation with curcumin and anise ground seeds on immune response (IgG, IgM, IgA) of broiler chicks (Ross 308) at 21,42 days of age.

\begin{tabular}{|c|c|c|c|c|c|c|}
\hline \multirow{2}{*}{ Items } & \multicolumn{3}{|c|}{ 21day } & \multicolumn{3}{|c|}{ 42day } \\
\hline & $\operatorname{IgG}(\mathrm{mg} / \mathrm{dl})$ & $\operatorname{IgM}(\mathrm{mg} / \mathrm{dl})$ & $\operatorname{IgA}(\mathrm{mg} / \mathrm{dl})$ & $\mathrm{IgG}(\mathrm{mg} / \mathrm{dl})$ & $\operatorname{IgM}(\mathrm{mg} / \mathrm{dl})$ & $\operatorname{IgA}(\mathrm{mg} / \mathrm{dl})$ \\
\hline \multicolumn{7}{|c|}{ Curcumin $(\mathrm{mg} / \mathrm{Kg})$} \\
\hline 0 & $776.00 \pm 31.18$ & $20.50 \pm 0.22$ & $66.17 \pm 1.20$ & $851.83 \pm 23.91$ & $23.00 \pm 0.45$ & $83.00 \pm 4.16$ \\
\hline 50 & $739.33 \pm 16.73$ & $20.00 \pm 0.78$ & $67.50 \pm 2.92$ & $900.00 \pm 11.95$ & $23.33 \pm 0.49$ & $90.33 \pm 2.54$ \\
\hline 100 & $733.33 \pm 20.38$ & $19.67 \pm 0.49$ & $66.50 \pm 3.03$ & $849.67 \pm 30.87$ & $23.67 \pm 0.42$ & $78.82 \pm 8.94$ \\
\hline \multicolumn{7}{|c|}{ Anise seeds $(\%)$} \\
\hline 0 & $779.17 \pm 28.51$ & $20.67 \pm 0.56$ & $64.67 \pm 0.99$ & $843.50 \pm 13.85$ & $22.50 \pm 0.43^{\mathrm{b}}$ & $82.00 \pm 2.46$ \\
\hline $0.5 \%$ & $724.00 \pm 21.58$ & $19.83 \pm 0.60$ & $64.83 \pm 2.57$ & $882.50 \pm 30.71$ & $23.67 \pm 0.42^{\mathrm{ab}}$ & $89.67 \pm 5.28$ \\
\hline $1 \%$ & $745.50 \pm 17.13$ & $19.67 \pm 0.42$ & $70.67 \pm 2.65$ & $875.50 \pm 26.94$ & $23.83 \pm 0.31^{\mathrm{a}}$ & $80.48 \pm 5.58$ \\
\hline \multicolumn{7}{|c|}{ Interactions } \\
\hline T1 & $860.00 \pm 40^{\mathrm{a}}$ & $21.00 \pm 0.00$ & $65.50 \pm 0.50$ & $832.00 \pm 22.00$ & $22.00 \pm 0.00$ & $77.00 \pm 1.00^{\mathrm{b}}$ \\
\hline $\mathrm{T} 2$ & $740.00 \pm 40^{\mathrm{b}}$ & $20.50 \pm 0.50$ & $64.50 \pm 3.50$ & $830.50 \pm 72.50$ & $23.00 \pm 1.00$ & $77.50 \pm 5.50^{\mathrm{ab}}$ \\
\hline T3 & $728.00 \pm 27^{b}$ & $20.00 \pm 0.00$ & $68.50 \pm 0.50$ & $893.00 \pm 17.00$ & $24.00 \pm 0.00$ & $94.50 \pm 5.50^{\mathrm{ab}}$ \\
\hline $\mathrm{T} 4$ & $731.50 \pm 12^{\mathrm{b}}$ & $21.50 \pm 1.50$ & $64.50 \pm 3.50$ & $877.50 \pm 12.50$ & $22.50 \pm 1.50$ & $84.00 \pm 4.00^{\mathrm{ab}}$ \\
\hline T5 & $750.00 \pm 40^{\mathrm{ab}}$ & $19.50 \pm 1.50$ & $64.00 \pm 6.00$ & $898.00 \pm 2.00$ & $24.00 \pm 0.00$ & $94.00 \pm 2.00^{\mathrm{ab}}$ \\
\hline T6 & $736.50 \pm 47^{b}$ & $19.00 \pm 1.00$ & $74.00 \pm 4.00$ & $924.50 \pm 29.50$ & $23.50 \pm 0.50$ & $93.00 \pm 4.00^{\mathrm{ab}}$ \\
\hline $\mathrm{T} 7$ & $746.00 \pm 23^{b}$ & $19.50 \pm 0.50$ & $64.00 \pm 1.00$ & $821.00 \pm 21.00$ & $23.00 \pm 0.00$ & $85.00 \pm 6.00^{\mathrm{ab}}$ \\
\hline $\mathrm{T} 8$ & $682.00 \pm 33^{b}$ & $19.50 \pm 1.50$ & $66.00 \pm 7.00$ & $919.00 \pm 63.00$ & $24.00 \pm 1.00$ & $97.50 \pm 12.50^{\mathrm{a}}$ \\
\hline T9 & $772.00 \pm 18^{\mathrm{ab}}$ & $20.00 \pm 1.00$ & $69.50 \pm 8.50$ & $809.00 \pm 51.00$ & $24.00 \pm 1.00$ & $53.95 \pm 1.05^{\mathrm{c}}$ \\
\hline
\end{tabular}

*T1 control (zero of curcumin or anise seeds), T2 (zero of curcumin and $0.5 \%$ anise seeds), T3 (zero of curcumin and $1 \%$ anise seeds), T4 (50 mg/kg curcumin and zero anise seeds), T5 (50 mg/kg curcumin and $0.5 \%$ anise seeds), T6 (50 mg $/ \mathrm{kg}$ curcumin and $1 \%$ anise seeds), $\mathrm{T} 7(100 \mathrm{mg} / \mathrm{kg}$ curcumin and zero anise seeds), T8 (100 mg/kg curcumin and $0.5 \%$ anise seeds), T9 (100 mg/kg curcumin and $1 \%$ anise seeds). ${ }^{\text {a b }}$ Means in the same columns with different superscript are significant different $(\mathrm{P}<0.05)$.

\subsubsection{Lymphoid organs}

Lymphoid organs effects by curcumin, anise ground seeds levels and their interactions are presented in Table (4) at age 42 days. The results showed that there were no significant effects $(P>0.05)$ of curcumin on bursa and spleen percentages at 42 days of age. Our results are in agreement with (Badran et al., 2020) who found that there was no significant effect on bursa of fabricius percentage when chicks fed diets containing curcumin (25 $\mathrm{mg} / \mathrm{kg}$ ) compared to the control chicks, and also spleen percentage when feeding chicks fed diets containing curcumin $(25,50$ and $100 \mathrm{mg} / \mathrm{kg})$ compared to the control. Sahoo et al. (2019) reported that there were no significant effects on spleen percentage and bursa of fabricius percentage when feeding diets containing turmeric (0.5and $1 \%$ ) compared to the control at age 35 days. Ahmed et al. (2018) found that there was no significant effect on bursa percentage when feeding chicks with diets containing turmeric $(0.25,0.50$ and $1 \%)$ compared to the control at age 42 day. Kafi et al. (2017) indicated that no significant effect on spleen percentage when feeding chicks diets containing turmeric $(0.50$ and $0.75 \%$ ) compared to the control at age 32 days. On the other hand, the obtained results are in disagreement with Badran et al. (2020) who reported that improved bursa of fabricius percentage was 
observed in broiler chickens (Ross 308) at 5 weeks of age when fed diets containing curcumin (50 and $100 \mathrm{mg} / \mathrm{kg}$ ) compared to the control. Ahmed et al. (2018) found that an improved spleen percentage was observed in broiler chickens (Ross 308) aged 42 days when fed diets containing turmeric $(0.25,0.50$ and $1 \%)$ compared to the control. However, the obtained results showed numerically improved spleen percentage of birds fed diets containing the second level of curcumin $(50 \mathrm{mg} / \mathrm{kg})$ when compared with the control and the third level $(100 \mathrm{mg} / \mathrm{kg})$ of curcumin at age 42 days. Regarding to the effect of anise seeds, there was no significant differences in bursa and spleen percentages due to anise seeds at 42 days at $P<0.05$.

Table (4): Effect of diet supplementation with curcumin and anise ground seeds on some lymphoid organs of broiler chicks (Ross 308) at 42 days of age.

\begin{tabular}{|c|c|c|c|c|c|}
\hline Items & Body weight (g) & Bursa (gm) & Bursa (\%) & Spleen $(\mathrm{gm})$ & Spleen $(\%)$ \\
\hline \multicolumn{6}{|c|}{ curcumin $(\mathrm{mg} / \mathrm{Kg})$} \\
\hline 0 & $2442 \pm 52.06$ & $1.602 \pm 0.190$ & $\cdot .066 \pm 0.008$ & $2.368 \pm 0.279$ & $0.097 \pm 0.012$ \\
\hline 50 & $2370 \pm 75.47$ & $1.307 \pm 0.138$ & $0.056 \pm 0.007$ & $2.368 \pm 0.278$ & $0.101 \pm 0.013$ \\
\hline 100 & $2495 \pm 79.65$ & $1.527 \pm 0.085$ & $0.062 \pm 0.005$ & $1.825 \pm 0.146$ & $0.074 \pm 0.007$ \\
\hline \multicolumn{6}{|c|}{ Anise seeds (\%) } \\
\hline 0 & $2454 \pm 60.02$ & $1.523 \pm 0.152$ & $0.063 \pm 0.007$ & $2.080 \pm 0.224$ & $0.085 \pm 0.009$ \\
\hline 0.5 & $2467 \pm 83.46$ & $1.265 \pm 0.092$ & $0.052 \pm 0.004$ & $2.140 \pm 0.241$ & $0.087 \pm 0.010$ \\
\hline 1 & $2386 \pm 70.72$ & $1.647 \pm 0.159$ & $0.069 \pm 0.006$ & $2.342 \pm 0.316$ & $0.100 \pm 0.015$ \\
\hline \multicolumn{6}{|c|}{ Interactions } \\
\hline T1 & $2530 \pm 20.00$ & $1.690 \pm 0.290^{\mathrm{ab}}$ & $0.067 \pm 0.012$ & $2.355 \pm 0.345$ & $0.094 \pm 0.015$ \\
\hline $\mathrm{T} 2$ & $2439.5 \pm 69.50$ & $1.150 \pm 0.090^{\mathrm{b}}$ & $0.047 \pm 0.005$ & $2.805 \pm 0.445$ & $0.115 \pm 0.015$ \\
\hline T3 & $2357 \pm 143$ & $1.965 \pm 0.325^{\mathrm{a}}$ & $0.083 \pm 0.009$ & $1.945 \pm 0.695$ & $0.085 \pm 0.035$ \\
\hline $\mathrm{T} 4$ & $2365 \pm 165$ & $1.510 \pm 0.450^{\mathrm{ab}}$ & $0.066 \pm 0.024$ & $2.370 \pm 0.340$ & $0.100 \pm 0.008$ \\
\hline T5 & $2454.5 \pm 210.5$ & $1.125 \pm 0.095^{\mathrm{b}}$ & $0.046 \pm 0.00$ & $1.845 \pm 0.085$ & $0.076 \pm 0.010$ \\
\hline T6 & $2290.5 \pm 20.5$ & $1.285 \pm 0.035^{\mathrm{ab}}$ & $0.056 \pm 0.001$ & $2.890 \pm 0.700$ & $0.127 \pm 0.032$ \\
\hline $\mathrm{T} 7$ & $2467 \pm 112$ & $1.370 \pm 0.090^{\mathrm{ab}}$ & $0.056 \pm 0.006$ & $1.515 \pm 0.205$ & $0.062 \pm 0.006$ \\
\hline $\mathrm{T} 8$ & $2506 \pm 230$ & $1.520 \pm 0.110^{\mathrm{ab}}$ & $0.062 \pm 0.010$ & $1.770 \pm 0.020$ & $0.072 \pm 0.008$ \\
\hline T9 & $2511 \pm 169$ & $1.690 \pm 0.190^{\mathrm{ab}}$ & $0.068 \pm 0.012$ & $2.190 \pm 0.210$ & $0.088 \pm 0.014$ \\
\hline
\end{tabular}

*T1 control (zero of curcumin or anise seeds), T2 (zero of curcumin and $0.5 \%$ anise seeds), T3 (zero of curcumin and $1 \%$ anise seeds), T4 (50 mg/kg curcumin and zero anise seeds), T5 (50 mg/kg curcumin and $0.5 \%$ anise seeds), T6 (50 mg/kg curcumin and $1 \%$ anise seeds), T7 (100 mg/kg curcumin and zero anise seeds), T8 (100 mg/kg curcumin and $0.5 \%$ anise seeds), T9 (100 mg/kg curcumin and $1 \%$ anise seeds). ${ }^{a-b}$ Means in the same columns with different superscript are significant different $(\mathrm{P}<0.05)$.

Our results are in agreement with Ramadan (2017) who found that no significant $(P>0.05)$ effects on spleen percentage when feeding chicks with diets containing anise seeds $(0.5,0.75$ and 1 $\mathrm{gm} / \mathrm{kg}$ ) compared to control one at age 42 days of age. Yazdi et al. (2014) reported that there was no significant effect on spleen percentage when feeding chicks with diets containing anise seeds $(1,5$ and $10 \mathrm{gm} / \mathrm{kg}$ ) compared to control at age 6 weeks. On the other hand, the obtained results are in disagreement with Ramadan (2017) who reported that improved bursa percentage was observed in broiler chickens (Cobb) fed diets containing anise seeds $(0.5,0.75$ and $1 \mathrm{gm} / \mathrm{kg})$ compared to the control at age 42 days of age. Yazdi et 
al. (2014) found that improved bursa percentage was observed in broiler chickens (Ross 308) fed diets containing anise seeds $(1,5$ and $10 \mathrm{gm} / \mathrm{kg}$ ) compared to the control at 6 weeks of age. Improved spleen percentage was observed in broiler chickens fed diets containing anise seeds $(0.5,1$ and $1.5 \mathrm{gm} / \mathrm{kg})$ compared to the control (Mahmood et al., 2014). However, our results showed that numerically improved in bursa and spleen percentages of birds fed diets containing anise seeds at level of $1 \%$ when compared with the control and $0.5 \%$ of anise seeds at age 42 day. No significant $(P>0.05)$ effects due to the interactions between curcumin and anise ground seeds levels on bursa and spleen percentages at 42 days of age.

\subsubsection{Economical evaluation of the different experimental diets}

The effects of curcumin, anise seed and their interactions on feed intake ( $\mathrm{kg} / \mathrm{bird})$, price $/ \mathrm{kg}$ feed, total feed cost, total production cost, body weight, price/kg body weight, total revenue, net revenue, economic feed efficiency percentage and relative economic feed efficiency of broiler chicks (Ross 308) are showed in Table (5) at age (1-42 day). Regarding the effect of curcumin, there were no significant $(P>0.05)$ differences due to curcumin levels on the all the previous parameters except for curcumin effect on total feed cost and total production cost at (1-42) days of age. However, birds fed diets containing curcumin (50 and 100 $\mathrm{mg} / \mathrm{kg}$ ) achieved a higher level in total feed cost and total production cost compared to controls. Also, lower economic feed efficiency percentage and relative economic feed efficiency of feeds for birds fed on diets containing curcumin (50 and $100 \mathrm{mg} / \mathrm{Kg}$ ) compared to the control. Our results are in agreement with Amein et al. (2020) who found that high total feed cost and total production cost were higher in broilers (Ross 308) fed with diets containing curcuma ( 0.3 or $0.5 \%$ ) compared to the control group. On the other hand, the obtained results are in disagreement with Amein et al. (2019) who reported that higher economic feed efficiency percentage and relative economic feed efficiency of feeds for birds fed with diets containing curcuma ( 0.3 or $0.5 \%$ ) compared to the control. The results showed that there were significant differences $(P<0.05)$ of anise seeds on total feed cost, total production cost, economic feed efficiency percentage and economic efficiency at age (1-42) days of age. Increased total feed cost and total production cost in broiler chickens (Ross 308) fed diets containing anise seeds (1 or $0.5 \%)$ respectively compared to the control. Also, decrease economic feed efficiency percentage in broiler chickens (Ross 308) fed diets containing anise seeds compared to the control. Decreased relative economic feed efficiency in broiler chickens (Ross 308) fed diets containing $1 \%$ anise seeds compared to the control and no significant differences $(P>0.05)$ between $(0.5 \%)$ and the control. Our results are in agreement with Amein et al. (2020) who found that 
high total feed cost and total production cost was higher in broilers (Ross 308) fed with diets containing anise seeds $(0.3$ and $0.6 \%$ ) compared to the control group. On the other hand, the obtained results are in disagreement with Amein et al. (2019) who reported that higher economic feed efficiency \%and relative economic feed efficiency of feeds for birds fed with diets containing anise seeds (0.3 and 6\%) compared to the control treatment. With regard to the effect of interactions between curcumin and anise ground seeds, there were statistically significant (P <0.05) effects attributable to the interactions between curcumin and anise seeds in total feed cost, total production cost, economic feed efficiency percentage and relative economic feed efficiency. T9 treatment was the highest in total feed cost and total production cost, while it was the lowest in the economic feed efficiency percentage and relative economic feed efficiency.

Table (5): The effect of curcumin, anise ground seeds and their interactions on the economical evaluation of broiler chickens at 42 days of age.

\begin{tabular}{|c|c|c|c|c|c|c|c|c|c|c|}
\hline Items & $\begin{array}{c}\text { Average feed } \\
\text { intake } \\
(\mathrm{kg} / \mathrm{bird})(\mathrm{a})\end{array}$ & $\begin{array}{l}\text { Price/kg feed } \\
\text { (L.E) (b) }\end{array}$ & $\begin{array}{l}\text { Total feed } \\
\text { cost (L.E) (c) }\end{array}$ & \begin{tabular}{|c|} 
Total \\
production cost \\
(L.E) (d)
\end{tabular} & $\begin{array}{l}\text { Body weight } \\
\text { (kg/bird) (e) }\end{array}$ & $\begin{array}{c}\text { Price } / k g \text { body } \\
\text { weight (L.E) })^{1}(f)\end{array}$ & $\begin{array}{l}\text { Total revenue } \\
\text { (L.E) (g) }\end{array}$ & $\begin{array}{l}\text { Net revenue } \\
\text { (L.E) (h) }\end{array}$ & $\begin{array}{l}\text { Economic feed } \\
\text { efficiency }(\%)\end{array}$ & $\begin{array}{c}\text { Relative } \\
\text { economic feed } \\
\text { efficiency }\end{array}$ \\
\hline \multicolumn{11}{|c|}{ Curcumin $(\mathrm{mg} / \mathrm{Kg})$} \\
\hline 0 & $3.87 \pm 0.07$ & $5.59 \pm 0.0$ & $21.66 \pm 1.47^{\mathrm{b}}$ & $31.91 \pm 1.47^{\mathrm{b}}$ & $2.45 \pm 0.04$ & $27.00 \pm 0.0$ & $66.06 \pm 1.17$ & $34.15 \pm 0.87$ & $107.04 \pm 2.46$ & $100.0 \pm 0.00$ \\
\hline 100 & $3.94 \pm 0.05$ & $5.94 \pm 0.00$ & $23.43 \pm 1.30^{\mathrm{a}}$ & $33.68 \pm 1.3^{\mathrm{a}}$ & $2.48 \pm 0.04$ & $27.00 \pm 0.00$ & $67.064 \pm 1.039$ & $33.382 \pm 0.90$ & $99.214 \pm 2.83$ & $92.69 \pm 2.64$ \\
\hline \multicolumn{11}{|c|}{ Anise seeds (\%) } \\
\hline 0 & $3.87 \pm 0.06$ & $.56 \pm 0.00$ & $21.51 \pm 0.43^{\mathrm{b}}$ & $31.76 \pm 0.43^{b}$ & $2.44 \pm 0.07$ & $27.00 \pm 0.00$ & $65.90 \pm 1.90$ & $34.15 \pm 1.58$ & $107.33 \pm 4.19^{\mathrm{a}}$ & $100.00 \pm 0.00^{\mathrm{a}}$ \\
\hline \multicolumn{11}{|c|}{ Interactions } \\
\hline $\mathrm{T} 1$ & $3.81 \pm 0.11$ & $5.40 \pm 0.00$ & $20.53 \pm 0.57^{\mathrm{d}}$ & $30.78 \pm 0.57^{\mathrm{d}}$ & & & $65.17 \pm 2.051$ & $34.39 \pm 2.15$ & $67 \pm 6.04^{\mathrm{a}}$ & $100.00 \pm 0.00^{\mathrm{a}}$ \\
\hline $\mathrm{T} 2$ & $3.88 \pm 0.20$ & $59 \pm 0.00$ & $21.68 \pm 1.91^{\mathrm{cd}}$ & $31.93 \pm 1.91^{\mathrm{cd}}$ & $2.46 \pm 0.11$ & $27.00 \pm 0.00$ & $66.45 \pm 2.83$ & $34.53 \pm 1.73$ & $108.01 \pm 1.79^{\text {ab }}$ & $96.72 \pm 1.61^{\mathrm{abc}}$ \\
\hline T3 & $3.93 \pm 0.04$ & $5.79 \pm 0.00$ & $22.79 \pm 0.26^{\text {abc }}$ & $33.04 \pm 0.26^{\text {abc }}$ & $2.47 \pm 0.05$ & $27.00 \pm 0.00$ & $66.56 \pm 1.29$ & $33.52 \pm 1.05$ & $101.43 \pm 2.50^{\mathrm{ab}}$ & $90.83 \pm 2.24^{\text {abc }}$ \\
\hline $\mathrm{T} 4$ & $3.92 \pm 0.16$ & $5.56 \pm 0.00$ & $21.77 \pm 0.86^{\text {bcd }}$ & $32.02 \pm 0.86^{\text {bed }}$ & $2.44 \pm 0.20$ & $27.00 \pm 0.00$ & $65.74 \pm 5.51$ & $33.72 \pm 4.65$ & $104.66 \pm 12.01^{\mathrm{ab}}$ & $93.72 \pm 10.75^{\text {abc }}$ \\
\hline T5 & $3.90 \pm 0.06$ & $5.77 \pm 0.00$ & $22.48 \pm 0.36^{\text {abcd }}$ & $32.73 \pm 0.36^{\text {abcd }}$ & $2.43 \pm 0.04$ & $27.00 \pm 0.00$ & $65.62 \pm 1.01$ & $32.88 \pm 0.80$ & $100.46 \pm 2.20^{\mathrm{ab}}$ & $89.96 \pm 1.97^{\text {abc }}$ \\
\hline T6 & $3.99 \pm 0.08$ & $5.97 \pm 0.00$ & $23.84 \pm 0.49^{\mathrm{ab}}$ & $34.09 \pm 0.49^{\mathrm{ab}}$ & $2.46 \pm 0.07$ & $27.00 \pm 0.00$ & $66.49 \pm 1.95$ & $32.40 \pm 1.47$ & $94.97 \pm 2.99^{\mathrm{ab}}$ & $85.04 \pm 2.68^{\mathrm{bc}}$ \\
\hline
\end{tabular}

*T1 control (zero of curcumin or anise seeds), T2 (zero of curcumin and $0.5 \%$ anise seeds), T3 (zero of curcumin and $1 \%$ anise seeds), T4 (50 mg/kg curcumin and zero anise seeds), T5(50 mg/kg curcumin and 0.5\% anise seeds), T6 (50 $\mathrm{mg} / \mathrm{kg}$ curcumin and $1 \%$ anise seeds), T7 (100 mg/kg curcumin and zero anise seeds), T8 (100 mg/kg curcumin and $0.5 \%$ anise seeds), T9 (100 mg/kg curcumin and $1 \%$ anise seeds). ${ }^{1}$ According to the local market price at the experimental time.

3.1.4 Efficiency nitrogen, calcium and phosphorus retention percentage

\subsubsection{Efficiency of nitrogen retention percentage}

The effects of curcumin and anise ground seeds and their interactions on efficiency nitrogen retention percentage are presented in Table (6) at age of 43-45 day.
Concerning with the effect of curcumin, there were no significant $(P<0.05)$ differences due to the curcumin for all nitrogen retention efficiency traits except of nitrogen retention efficiency percentage. Birds fed $(100 \mathrm{mg}$ curcumin $/ \mathrm{kg}$ feed) had a significantly $(P<0.05)$ the lowest nitrogen retention efficiency percentage than those in 50 
$\mathrm{mg} / \mathrm{kg}$ and control groups. Regarding the effect of anise seeds, there were statistically no significant $(P<0.05)$ differences due to the anise ground seeds for all nitrogen retention efficiency traits except of nitrogen excreta. Birds fed 1\% anise seeds had a significantly $(P<0.05)$ the lowest nitrogen excreta than those in $0.5 \%$. However, there was a numerical decrease in nitrogen retention percentage for birds fed diets containing ground anise seeds.

Table (6): The effects of curcumin and anise seeds and their interactions on nitrogen retention efficiency of broiler chicks.

\begin{tabular}{|c|c|c|c|c|c|c|c|}
\hline \multirow{2}{*}{ Items } & \multicolumn{7}{|c|}{ Nitrogen retention efficiency percentage } \\
\hline & Dry feed $(\mathrm{g})$ & $\mathrm{N}(\%)$ & $\mathrm{N} /$ feed $(\mathrm{g})$ & Dry excreta $(\mathrm{g})$ & $\mathrm{N}$ excreta $(\%)$ & N/excreta $(g)$ & $\mathrm{N}$ retention $(\%)$ \\
\hline \multicolumn{8}{|c|}{ Curcumin $(\mathrm{mg} / \mathrm{Kg})$} \\
\hline 0 & $142.17 \pm 11.27$ & $3.07 \pm 0.00$ & $4.37 \pm 0.36$ & $20.25 \pm 2.22$ & $4.96 \pm 0.47$ & $0.98 \pm 0.11$ & $77.30 \pm 2.12^{\mathrm{a}}$ \\
\hline 50 & $141.84 \pm 7.71$ & $3.03 \pm 0.00$ & $4.29 \pm 0.22$ & $21.75 \pm 2.34$ & $5.60 \pm 0.30$ & $1.23 \pm 0.17$ & $71.80 \pm 2.82^{\mathrm{ab}}$ \\
\hline 100 & $138.09 \pm 5.57$ & $3.01 \pm 0.00$ & $4.16 \pm 0.18$ & $22.37 \pm 1.89$ & $6.07 \pm 0.66$ & $1.33 \pm 0.13$ & $68.04 \pm 2.80^{\mathrm{b}}$ \\
\hline \multicolumn{8}{|c|}{ Anise seeds $(\%)$} \\
\hline 0 & $132.54 \pm 12.16$ & $3.06 \pm 0.00$ & $4.07 \pm 0.39$ & $19.25 \pm 1.93$ & $4.90 \pm 0.30$ & $0.93 \pm 0.09^{\mathrm{b}}$ & $76.65 \pm 2.17$ \\
\hline $0.5 \%$ & $151.06 \pm 2.67$ & $3.02 \pm 0.00$ & $4.56 \pm 0.08$ & $24.66 \pm 2.00$ & $5.66 \pm 0.38$ & $1.38 \pm 0.12^{\mathrm{a}}$ & $69.66 \pm 2.56$ \\
\hline $1 \%$ & $138.50 \pm 3.03$ & $3.03 \pm 0.00$ & $4.20 \pm 0.16$ & $20.46 \pm 1.86$ & $6.07 \pm 0.71$ & $1.23 \pm 0.16^{\mathrm{ab}}$ & $70.83 \pm 3.48$ \\
\hline \multicolumn{8}{|c|}{ Interactions } \\
\hline $\mathrm{T} 1$ & $147.47 \pm 39.40$ & $3.14 \pm 0.00^{\mathrm{a}}$ & $4.63 \pm 1.24$ & $20.57 \pm 4.65$ & $4.03 \pm 0.18$ & $0.82 \pm 0.15$ & $81.86 \pm 1.58^{\mathrm{a}}$ \\
\hline $\mathrm{T} 2$ & $151.72 \pm 3.00$ & $3.05 \pm 0.00^{\mathrm{d}}$ & $4.63 \pm 0.09$ & $23.95 \pm 4.20$ & $5.60 \pm 1.40$ & $1.28 \pm 0.10$ & $72.25 \pm 2.71^{\mathrm{ab}}$ \\
\hline T3 & $127.31 \pm 2.11$ & $3.02 \pm 0.00^{\mathrm{e}}$ & $3.85 \pm 0.06$ & $16.23 \pm 2.16$ & $5.25 \pm 0.00$ & $0.85 \pm 0.11$ & $77.80 \pm 3.31^{\mathrm{ab}}$ \\
\hline $\mathrm{T} 4$ & $125.23 \pm 17.24$ & $3.10 \pm 0.00^{\mathrm{b}}$ & $3.88 \pm 0.53$ & $18.35 \pm 4.70$ & $5.08 \pm 0.18$ & $0.92 \pm 0.21$ & $76.50 \pm 2.09^{\mathrm{ab}}$ \\
\hline T5 & $154.21 \pm 6.69$ & $3.00 \pm 0.00^{\mathrm{f}}$ & $4.62 \pm 0.20$ & $23.78 \pm 6.21$ & $5.43 \pm 0.18$ & $1.30 \pm 0.38$ & $72.17 \pm 6.98^{\mathrm{ab}}$ \\
\hline T6 & $146.09 \pm 10.17$ & $3.00 \pm 0.00^{\mathrm{f}}$ & $4.38 \pm 0.30$ & $23.11 \pm 2.03$ & $6.30 \pm 0.70$ & $1.47 \pm 0.29$ & $66.74 \pm 4.29^{\mathrm{ab}}$ \\
\hline $\mathrm{T} 7$ & $124.93 \pm 5.91$ & $2.96 \pm 0.00^{\mathrm{g}}$ & $3.69 \pm 0.17$ & $18.83 \pm 3.11$ & $5.60 \pm 0.00$ & $1.05 \pm 0.17$ & $71.59 \pm 3.37^{\mathrm{ab}}$ \\
\hline $\mathrm{T} 8$ & $147.24 \pm 5.31$ & $3.00 \pm 0.00^{f}$ & $4.41 \pm 0.16$ & $26.25 \pm 0.38$ & $5.95 \pm 0.00$ & $1.56 \pm 0.20$ & $64.56 \pm 1.79^{\mathrm{b}}$ \\
\hline T9 & $142.09 \pm 1.35$ & $3.07 \pm 0.00^{c}$ & $4.37 \pm 0.35$ & $22.04 \pm 3.99$ & $6.65 \pm 2.45$ & $1.37 \pm 0.27$ & $67.96 \pm 8.85^{\mathrm{ab}}$ \\
\hline
\end{tabular}

*T1 control (zero of curcuma or anise seeds), T2 (zero of curcuma and $0.5 \%$ anise seeds), T3 (zero of curcuma and $1 \%$ anise seeds), T4 (50 mg/kg curcuma and zero anise seeds), T5 (50 mg/kg curcuma and $0.5 \%$ anise seeds), T6 (50 mg/kg curcuma and 1\% anise seeds), T7 (100 mg/kg curcuma and zero anise seeds), T8 (100 mg/kg curcuma and $0.5 \%$ anise seeds), T9 (100 mg/kg curcuma and $1 \%$ anise seeds). ${ }^{\mathrm{a}-\mathrm{b}}$ Means in the same columns with different superscript are significant different $(\mathrm{P}<0.05)$.

Regarding the effect of interactions curcumin and anise seeds, there were statistically significant at $(\mathrm{P}<0.05)$ differences due to interactions curcumin and anise seeds on nitrogen retention percentage. Nitrogen retention percentage was decreased for all interactions compared to control. The T8 $(100 \mathrm{mg}$ curcumin $/ \mathrm{kg}$ feed $\times 0.5 \%$ anise seeds) was the lowest.

\subsubsection{Efficiency of calcium retention percentage}

The effects of curcumin and anise seeds and their interactions on efficiency of calcium retention percentage are presented in Table (7) at age 43-45 days of age. Concerning with the effect of curcumin, there were no significant $(P>0.05)$ differences due to the curcumin for all calcium retention efficiency. However, there was a numerical decrease in calcium retention percentage for birds fed diets containing curcumin. Regarding the effect of anise seeds, there were statistically no significant $(P>0.05)$ 
differences due to the anise seeds for all nitrogen retention efficiency traits except of calcium \% in diet, calcium excreta (\%), calcium excreta and calcium retention percentage. Regarding the effect of anise seeds, there were statistically significant $(P<0.05)$ differences due to anise seeds on calcium retention percentage.

Table (7): The effects of curcumin and anise seeds and their interactions on calcium retention efficiency of broiler chicks.

\begin{tabular}{|c|c|c|c|c|c|c|c|}
\hline \multirow{2}{*}{ Items } & \multicolumn{7}{|c|}{ Calcium retention efficiency percentage } \\
\hline & Dry feed (g) & $\mathrm{Ca}(\%)$ & $\mathrm{Ca} /$ feed $(\mathrm{g})$ & Dry excreta $(\mathrm{g})$ & Ca excreta $(\%)$ & $\mathrm{Ca} /$ excreta $(\mathrm{g})$ & Ca retention $(\%)$ \\
\hline \multicolumn{8}{|c|}{ Curcumin $(\mathrm{mg} / \mathrm{Kg})$} \\
\hline 0 & $142.17 \pm 11.27$ & $1.25 \pm 0.00$ & $1.78 \pm 0.18$ & $20.25 \pm 2.22$ & $2.07 \pm 0.11$ & $0.42 \pm 0.05$ & $76.09 \pm 2.59$ \\
\hline 50 & $141.84 \pm 7.71$ & $1.17 \pm 0.00$ & $1.65 \pm 0.08$ & $21.75 \pm 2.34$ & $2.07 \pm 0.14$ & $0.46 \pm 0.07$ & $72.60 \pm 3.41$ \\
\hline 100 & $138.09 \pm 5.57$ & $1.08 \pm 0.00$ & $1.48 \pm 0.07$ & $22.37 \pm 1.89$ & $2.02 \pm 0.07$ & $0.45 \pm 0.04$ & $69.11 \pm 3.31$ \\
\hline \multicolumn{8}{|c|}{ Anise seeds $(\%)$} \\
\hline 0 & $132.54 \pm 12.16$ & $1.30 \pm 0.00^{\mathrm{a}}$ & $1.73 \pm 0.18$ & $19.25 \pm 1.93$ & $1.88 \pm 0.08^{\mathrm{b}}$ & $0.36 \pm 0.04^{b}$ & $78.88 \pm 1.65^{\mathrm{a}}$ \\
\hline $0.5 \%$ & $151.06 \pm 2.67$ & $1.06 \pm 0.00^{\mathrm{b}}$ & $1.60 \pm 0.10$ & $24.66 \pm 2.00$ & $2.05 \pm 0.09^{\mathrm{ab}}$ & $0.51 \pm 0.06^{\mathrm{a}}$ & $67.45 \pm 3.99^{\mathrm{b}}$ \\
\hline $1 \%$ & $138.50 \pm 3.03$ & $1.14 \pm 0.00^{\mathrm{b}}$ & $1.58 \pm 0.08$ & $20.46 \pm 1.86$ & $2.24 \pm 0.11^{\mathrm{a}}$ & $0.45 \pm 0.04^{\mathrm{ab}}$ & $71.48 \pm 1.45^{\mathrm{ab}}$ \\
\hline \multicolumn{8}{|c|}{ Interactions } \\
\hline $\mathrm{T} 1$ & $147.47 \pm 39.40$ & $1.38 \pm 0.00$ & $2.04 \pm 0.54$ & $20.57 \pm 4.65$ & $1.75 \pm 0.04^{\mathrm{c}}$ & $0.36 \pm 0.07$ & $82.13 \pm 1.20^{\mathrm{a}}$ \\
\hline $\mathrm{T} 2$ & $151.72 \pm 3.00$ & $1.22 \pm 0.00$ & $1.85 \pm 0.04$ & $23.95 \pm 4.20$ & $2.11 \pm 0.08^{\mathrm{abc}}$ & $0.51 \pm 0.11$ & $72.57 \pm 5.31^{\mathrm{ab}}$ \\
\hline T3 & $127.31 \pm 2.11$ & $1.14 \pm 0.00$ & $1.45 \pm 0.02$ & $16.23 \pm 2.16$ & $2.36 \pm 0.00^{\mathrm{ab}}$ & $0.38 \pm 0.05$ & $73.57 \pm 3.94^{\mathrm{ab}}$ \\
\hline T4 & $125.23 \pm 17.24$ & $1.22 \pm 0.00$ & $1.53 \pm 0.21$ & $18.35 \pm 4.70$ & $1.79 \pm 0.08^{\mathrm{c}}$ & $0.32 \pm 0.07$ & $79.00 \pm 1.63^{\mathrm{a}}$ \\
\hline T5 & $154.21 \pm 6.69$ & $1.06 \pm 0.00$ & $1.63 \pm 0.07$ & $23.78 \pm 6.21$ & $1.99 \pm 0.28^{\mathrm{bc}}$ & $0.49 \pm 0.19$ & $70.40 \pm 10.42^{\mathrm{ab}}$ \\
\hline T6 & $146.09 \pm 10.17$ & $1.22 \pm 0.00$ & $1.78 \pm 0.12$ & $23.11 \pm 2.03$ & $2.44 \pm 0.00^{\mathrm{a}}$ & $0.56 \pm 0.05$ & $68.41 \pm 0.57^{\mathrm{ab}}$ \\
\hline T7 & $124.93 \pm 5.91$ & $1.30 \pm 0.00$ & $1.62 \pm 0.08$ & $18.83 \pm 3.11$ & $2.11 \pm 0.08^{\mathrm{abc}}$ & $0.40 \pm 0.08$ & $75.51 \pm 3.83^{\mathrm{a}}$ \\
\hline T8 & $147.24 \pm 5.31$ & $0.89 \pm 0.00$ & $1.31 \pm 0.05$ & $26.25 \pm 0.38$ & $2.03 \pm 0.16^{\mathrm{abc}}$ & $0.53 \pm 0.04$ & $59.37 \pm 1.21^{\mathrm{b}}$ \\
\hline T9 & $142.09 \pm 1.35$ & $1.06 \pm 0.00$ & $1.51 \pm 0.12$ & $22.04 \pm 3.99$ & $1.91 \pm 0.12^{\mathrm{c}}$ & $0.42 \pm 0.05$ & $72.46 \pm 1.07^{\mathrm{ab}}$ \\
\hline
\end{tabular}

*T1 control (zero of curcumin or anise seeds), T2 (zero of curcumin and $0.5 \%$ anise seeds), T3 (zero of curcumin and $1 \%$ anise seeds), T4 (50 mg/kg curcumin and zero anise seeds), T5 (50 mg/kg curcumin and $0.5 \%$ anise seeds), T6 (50 mg/kg curcumin and $1 \%$ anise seeds), T7 (100 mg/kg curcumin and zero anise seeds), T8 (100 $\mathrm{mg} / \mathrm{kg}$ curcumin and $0.5 \%$ anise seeds), T9 $\left(100 \mathrm{mg} / \mathrm{kg}\right.$ curcumin and $1 \%$ anise seeds). ${ }^{\mathrm{a}-\mathrm{b}}$ Means in the same columns with different superscript are significant different $(\mathrm{P}<0.05)$.

Increased calcium excreta percentage and calcium excreta in birds fed on diets containing anise seeds at levels of $(0.50$ and $1 \%$ ) compared to the control. Also, decreased calcium retention percentage in birds fed on diets containing anise seeds $(0.50$ and $1 \%)$ respectively compared to the control. Regarding the effect of interactions curcumin and anise seeds, there were statistically no significant $(P>0.05)$ differences due to interactions curcumin and anise seeds for all nitrogen retention efficiency traits except of calcium excreta \%and calcium retention percentage. Birds fed diets containing (50 $\mathrm{mg}$ curcumin $/ \mathrm{kg}$ feed $\times 1 \%$ anise) were significantly higher $(P<0.05)$ in calcium excreta percentage than the rest of the interactions.

\subsubsection{Efficiency of phosphorus retention percentage}

The effects of curcumin, anise seeds and their interactions on efficiency phosphorus retention percentage is presented in Table (8) at age 43-45day. Regarding the effect of curcumin, anise seeds and their interactions, there were statistically no significant $(P<0.05)$ differences due to curcumin on phosphorus retention percentage. 
Table (8): The effects of curcumin and anise seeds and their interactions on phosphorus retention efficiency of broiler chicks.

\begin{tabular}{|c|c|c|c|c|c|c|c|}
\hline \multirow{2}{*}{ Items } & \multicolumn{7}{|c|}{ Phosphorus retention efficiency percentage } \\
\hline & Dry feed $(\mathrm{g})$ & $\mathrm{P}(\%)$ & $\mathrm{P} /$ feed $(\mathrm{g})$ & Dry excreta $(\mathrm{g})$ & P/excreta (\%) & P/excreta $(\mathrm{g})$ & $\mathrm{P} /$ retention $(\%)$ \\
\hline \multicolumn{8}{|c|}{ Curcumin $(\mathrm{mg} / \mathrm{Kg})$} \\
\hline 0 & $142.17 \pm 11.27$ & $0.57 \pm 0.00^{\mathrm{b}}$ & $0.81 \pm 0.07$ & $20.25 \pm 2.22$ & $1.75 \pm 0.24$ & $0.36 \pm 0.07$ & $55.57 \pm 7.71$ \\
\hline 50 & $141.84 \pm 7.71$ & $0.57 \pm 0.00^{\mathrm{b}}$ & $0.81 \pm 0.04$ & $21.75 \pm 2.34$ & $1.97 \pm 0.09$ & $0.42 \pm 0.04$ & $47.90 \pm 2.69$ \\
\hline 100 & $138.09 \pm 5.57$ & $0.62 \pm 0.00^{\mathrm{a}}$ & $0.85 \pm 0.03$ & $22.37 \pm 1.89$ & $1.74 \pm 0.13$ & $0.39 \pm 0.04$ & $54.76 \pm 4.94$ \\
\hline \multicolumn{8}{|c|}{ Anise seeds (\%) } \\
\hline 0 & $132.54 \pm 12.16$ & $0.61 \pm 0.00^{\mathrm{a}}$ & $0.81 \pm 0.07$ & $19.25 \pm 1.93$ & $1.96 \pm 0.16$ & $0.37 \pm 0.03$ & $53.79 \pm 4.03$ \\
\hline $0.5 \%$ & $151.06 \pm 2.67$ & $0.56 \pm 0.00^{\mathrm{b}}$ & $0.85 \pm 0.01$ & $24.66 \pm 2.00$ & $1.80 \pm 0.19$ & $0.45 \pm 0.06$ & $47.10 \pm 7.33$ \\
\hline $1 \%$ & $138.50 \pm 3.03$ & $0.59 \pm 0.00^{\mathrm{ab}}$ & $0.81 \pm 0.04$ & $20.46 \pm 1.86$ & $1.70 \pm 0.13$ & $0.35 \pm 0.04$ & $57.34 \pm 4.17$ \\
\hline \multicolumn{8}{|c|}{ Interactions } \\
\hline $\mathrm{T} 1$ & $147.47 \pm 39.40$ & $0.60 \pm 0.00$ & $0.89 \pm 0.24$ & $20.57 \pm 4.65$ & $2.23 \pm 0.40$ & $0.44 \pm 0.02$ & $47.40 \pm 11.70$ \\
\hline $\mathrm{T} 2$ & $151.72 \pm 3.00$ & $0.56 \pm 0.00$ & $0.85 \pm 0.02$ & $23.95 \pm 4.20$ & $1.60 \pm 0.56$ & $0.41 \pm 0.20$ & $52.69 \pm 22.67$ \\
\hline T3 & $127.31 \pm 2.11$ & $0.55 \pm 0.00$ & $0.70 \pm 0.01$ & $16.23 \pm 2.16$ & $1.42 \pm 0.07$ & $0.23 \pm 0.04$ & $66.64 \pm 6.60$ \\
\hline $\mathrm{T} 4$ & $125.23 \pm 17.24$ & $0.58 \pm 0.00$ & $0.73 \pm 0.10$ & $18.35 \pm 4.70$ & $1.94 \pm 0.30$ & $0.34 \pm 0.04$ & $52.75 \pm 1.45$ \\
\hline $\mathrm{T} 5$ & $154.21 \pm 6.69$ & $0.54 \pm 0.00$ & $0.83 \pm 0.04$ & $23.78 \pm 6.21$ & $2.01 \pm 0.15$ & $0.47 \pm 0.09$ & $44.23 \pm 8.18$ \\
\hline T6 & $146.09 \pm 10.17$ & $0.58 \pm 0.00$ & $0.85 \pm 0.06$ & $23.11 \pm 2.03$ & $1.97 \pm 0.01$ & $0.46 \pm 0.04$ & $46.72 \pm 1.21$ \\
\hline $\mathrm{T} 7$ & $124.93 \pm 5.91$ & $0.66 \pm 0.00$ & $0.82 \pm 0.04$ & $18.83 \pm 3.11$ & $1.70 \pm 0.09$ & $0.32 \pm 0.04$ & $61.23 \pm 2.68$ \\
\hline $\mathrm{T} 8$ & $147.24 \pm 5.31$ & $0.58 \pm 0.00$ & $0.86 \pm 0.03$ & $26.25 \pm 0.38$ & $1.80 \pm 0.35$ & $0.47 \pm 0.10$ & $44.38 \pm 13.37$ \\
\hline T9 & $142.09 \pm 1.35$ & $0.62 \pm 0.00$ & $0.89 \pm 0.07$ & $22.04 \pm 3.99$ & $1.71 \pm 0.33$ & $0.36 \pm 0.01$ & $58.66 \pm 3.87$ \\
\hline
\end{tabular}

*T1 control (zero of curcumin or anise seeds), T2 (zero of curcumin and $0.5 \%$ anise seeds), T3 (zero of curcumin and $1 \%$ anise seeds), T4 (50 mg/kg curcumin and zero anise seeds), T5 (50 mg/kg curcumin and $0.5 \%$ anise seeds), T6 (50 mg/kg curcumin and $1 \%$ anise seeds), T7 (100 mg/kg curcumin and zero anise seeds), T8 (100 $\mathrm{mg} / \mathrm{kg}$ curcumin and $0.5 \%$ anise seeds), T9 (100 mg/kg curcumin and $1 \%$ anise seeds). ${ }^{\mathrm{a}-\mathrm{b}}$ Means in the same columns with different superscript are significant different $(\mathrm{P}<0.05)$.

\section{Discussion}

According to Zhu et al. (2014), curcumin has properties that can improve immunity and protein metabolism, as well as protective effects on cells, via enzymatic and non-enzymatic mechanisms. Therefore, based on the increase in serum globulins, we suggest that curcumin exerts beneficial effects on the host immune responses, which could be associated with the presence of carotenoid compounds that can contribute to modulating the immune response by inducing lymphocyte proliferation and increasing antibody production (Chew and Park, 2004; Rajput et al., 2013). Liu et al. (2020) indicated that supplemental $150 \mathrm{mg} / \mathrm{kg}$ curcumin can improve productive performance, antioxidant enzyme activity, and immune function in laying hens under the heat stress condition. This indicates that curcumin has a certain regulatory effect on the humoral immunity of laying hens in a high-temperature environment and can enhance the body's immunity by increasing serum immunoglobulin levels, which is consistent with the fore mentioned studies on the effects of curcumin on animal immune function. These positive effects of using turmeric might be due to its anti-inflammatory, antioxidant, and antibacterial activity. The addition of curcumin in animal diets may improve nutrient digestion and metabolism by stimulating bile acid secretion and activation of digestive enzyme activities (Chattopadhyay et al., 2004, Platel and Srinivasan, 2000). Curcumin has been shown to possess antioxidant, anti-inflammatory, antimuta- 
genic, antimicrobial, and anticancer properties (Hewlings and Kalman, 2017; Priyadarsini, 2014). Anise seeds antifungal, hypothermic, anti-viral, antibacterial, and antioxidant (Cifftci et al.,2005). Improved immunoglobulin A (IgA), immunoglobulin $\mathrm{M}$ ( $\operatorname{IgM})$ was observed in birds 3- and 5-weeks old broiler chickens (Cobb) fed diets containing anise seeds $(0.25,0.50,0.75$ $\mathrm{gm} / \mathrm{kg}$ ) compared to the control and immunoglobulin $\mathrm{g}(\mathrm{IgG})$ in birds 5-weekold broiler chickens (Cobb) fed diets containing anise seeds $(0.25,0.50,0.75$ $\mathrm{gm} / \mathrm{kg}$ ) compared to the control (Barakat et al., 2016).

\section{Conclusion}

It was recommended that curcumin should be add at level of $50 \mathrm{mg} / \mathrm{kg}$ diet or 100 $\mathrm{mg} / \mathrm{kg}$ curcumin plus $0.5 \%$ anise ground seeds to achieve higher immunity and economical evaluation of broiler chicken (Ross 308).

\section{References}

Abe, Y., Hashimoto, S. and Horie, T. (1999), "Curcumin inhibition of inflammatory cytokine production by human peripheral blood monocytes and alveolar macrophages", Pharmacological Research, Vol. 39 No. 1, pp. 41-47

Ahmed, I., El-Rayes, T. and AlShaymaa, I. A. (2018), "Assessment of dietary supplementation of turmeric (Curcuma longa) as a photobiotic on broiler performance and bacterial count", Egyptian Journal Nutrition and Feeds, Vol. 21 No. 2, pp. 519528.

Alagawany, M., Ashour, E. A. and Reda, F. M. (2016), "Effect of dietary supplementation of garlic (Allium sativum) and turmeric (Curcuma longa) on growth performance, carcass traits, blood profile and oxidative status in growing rabbits", Journal Annals of Animal Science, Vol. 16 No. 2, pp. 489-505

Amein, S. M., Gamal, M. M. and Mohammed, K. H. (2019), "Effect of some medicinal plants as feed additives on growth performance, blood constituents and carcass characteristics of broilers ", Journal of Advanced Veterinary Research, Vol. 9 No. 4, pp.170-177.

AOAC (1990), Official methods of analysis, $13^{\text {th }}$ Ed., Association of official analytical chemists, Washington, DC, USA.

Arshami, J., Pilevar, M., Azghadi, M. A. and Raji, A. R. (2013), "Hypolipidemic and antioxidative effects of curcumin on blood parameters, humoral immunity, and jejunum histology in Hy-line hens", Avicenna journal of phytomedicine, Vol. 3 No. 2, pp. 178-185.

Attia, Y. A. (1986), Effect of different dietary levels of protein and energy in productive performance of white leghorn chickens, M.Sc. Thesis, Faculty of Veterinary Medicine, Al- 
Azhar University, Cairo, Egypt.

Badran, A. M. M., Hamdy, A. B., Mohamed, A. E. and AbdelMoneim, E. (2020), "Effect of dietary curcumin and curcumin nanoparticles supplementation on growth performance, immune response and anti-oxidant of broilers chickens", Egyptian Poultry Science Journal, Vol. 40 No. 1, pp. 325-343.

Barakat, D. M., Ali, H. E., Kadry, M. S., Usama, E. M., Hany, F. E. and Mervat, A. A. (2016), "Anise (Pimpinella anisum) enhances the growth performance, immunity and antioxidant activities in broilers", International Journal of Pharmaceutical Sciences Review and Research, Vol. 37 No. 2, pp. 134-140

Bayoumi, S. B. (1980), Effect of different ration on egg production of breeding hens, M.Sc. Thesis, Faculty of Agriculture, Kafr El-Sheikh Tanta University, Egypt.

Chattopadhyay, I., Biswas, K., Bandyopadhyay, U. and Banerjee, R. K. (2004), "Turmeric and curcumin: Biological actions and medicinal applications", Current ScienceBangalore, Vol. 87 No.1, pp 44-53.

Chew, B. P. and Park, J. S. (2014), "Carotenoid action on the immune response", The Journal of Nutrition, Vol. 134 No.1, pp. 257261.

Christaki, E., Bonos, E., Giannenas, I. and Florou-Paneri, P. (2012), "Aromatic plants as a source of bioactive compounds", Agriculture, Vol. 2 No. 3, pp. 228-243.

Cifftci, M., Guler, T., Dalkilic, B. and Ertas, O. N. (2005), "The effect of anise oil (Pimpinella anisum L.) on broiler performance", International Journal of Poultry Science, Vol. 4 No. 11, pp. 851-855.

Duncan's, D. B. (1955), 'Multiple range and multiple F tests", Biometrics, Vol. 11, pp. 1-42.

Graña, A. L., F. D. C., Tavernari, G. R., Lelis, L. F. T., Albino, H. S., Rostagno, and P. C. Gomes (2013), "Evaluation of nutrient excretion and retention in broilers submitted to different nutritional strategies", Brazilian Journal of Poultry Science, Vol. 15 No. 2, pp. 161-168.

Hewlings, S. J. and Kalman, D. S. (2017), "Curcumin: A review of its' effects on human health", Foods, Vol. 92 No. 6, pp. 1-11.

Kafi, A., Uddin, M. N., Uddin, M. J., Khan, M. M. H. and Haque, M. E. (2017), "Effect of dietary supplementation of turmeric (Curcuma longa), ginger (Zingiber officinale) and their combination as feed additives on feed intake, growth performance and economics of broiler", International Journal of Poultry Science, Vol. 16 No. 7, pp. 257-265.

Kiuchi, F., Goto, Y., Sugimoto, N., Akao, N., Kondo, K. and Tsuda, Y. (1993), 
"Nematocidal activity of turmeric: synergistic action of curcuminoids", Chemical and Pharmaceutical Bulletin, Vol. 41 No. 9, pp. 16401643.

Liu, M., Yinglin, L., Peng, G., Xiaolei, X., Dongfeng, L., Debing, Y. and Minli, Y. (2020), "Effect of curcumin on laying performance, egg quality, endocrine hormones, and immune activity in heat-stressed hens", Poultry Science, Vol. 99 No. 4, pp. 2196-2202.

Mahmood, M. S., Muhammad, F. A, Iftikhar, H., Rao, Z. A., Ahrar, K. and Azhar, R. (2014), "Growth promoting effect of Pimpinella anisum (Aniseed) in broiler chickens", Bole tin Latino Americano y del Caribe de Plants Medicinales y Aromatics, Vol. 13 No. 3, pp. 278284.

Motlaq, A. M. and Sadik, H. L. (2012), "Effect of supplementing different combination levels of crushed Seeds of fenugreek and anise to the diets on productive performance of broiler", Al-Anbar Journal of Veterinary Sciences, Vol. 5 No. 2, pp. 83-90.

Murugesan, G. R., Syed, B., Haldar, S. and Pender, C. (2015), "Phytogenic feed additives as an alternative to antibiotic growth promoters in broiler chickens", Journal Frontiers in Veterinary Science, Vol. 2 No. 21, pp 1-6.

NRC (1994), Nutrient requirements of poultry, $9^{\text {th }}$ Ed., National Academy
Press, Washington, DC, USA.

Platel, K. and Srinivasan, K. (2000), "Influence of dietary spices and their active principles on pancreatic digestive enzymes in albino rats", Nahrung, Vol. 44 No 1, pp. 42-46.

Priyadarsini, K. (2014), "The chemistry of curcumin: From extraction to therapeutic agent", Molecules Journal, Vol. 19 No.12, pp. 2009120112.

Rajput, N., Muhammah, N., Yan, R., Zhong, X. and Wang, T. (2013), "The effect of dietary supplementation with the natural carotenoids curcumin and lutein on broiler pigmentation and immunity", Journal of Poultry Science, Vol. 92 No. 5, pp. 1177-1185

Ramadan, S. G. A. (2017), "Behavior, fear response, performance and immune response of broiler chicks fed graded levels of anise seed as alternative to antibiotics", Alexandria Journal of Veterinary Sciences, Vol. 55 No. 2, pp. 74-82.

Sahoo, N., Mishra, S. K., Swain, R. K., Acharya, A. P., Pattnaik, S., Sethy, K. and Sahoo, L. (2019), "Effect of turmeric and ginger supplementation on immunity, antioxidant, liver enzyme activity, gut bacterial load and histopathology of broilers", Indian Journal of Animal Sciences, Vol. 89 No. 7, pp 774-779.

SAS Institute (2006), SAS Users Guide Statistics Version $10^{\text {th }}, 16^{\text {th }}$ Edition, 
SAS Institute, Cary, North Carolina, USA.

South, E., Exon, J. and Hendrix, K. (1997), "Dietary curcumin enhances antibody response in rats", Immunopharmacology and immunetoxicology Journal, Vol. 19 No .1, pp. 105-119.

Yazdi, F. F., Ghalamkari, G., Toghiani, M., Modaresi, M. and Landy, N. (2014), "Anise seed (Pimpinella anisum L.) as an alternative to antibiotic growth promoters on performance, carcass traits and immune responses in broiler chicks", Asian Pacific Journal of Tropical Disease, Vol. 4 No. 6, pp. 447-451.
Zhang, G. F., Yang, Z. B., Wang, Y., Yang, W. R., Jiang, S. Z. and Gai, G. S. (2009), "Effects of ginger root (Zingiber officinale) processed to different particle sizes on growth performance, antioxidant status and serum metabolites of broiler chickens", Journal Poultry Science, Vol. 88 No. 10, pp. 2159-2166.

Zhu, X., Liu W., Yuan. S. and Chen, H. (2014), "The effect of different dietary levels of Thyme Essential Oil on serum biochemical Indices in Mahua broiler chickens", Italian Journal of Animal Science, Vol. 13 No. 3, pp. 576-581. 